\title{
A face visível da Aids
}

\section{The visible face of Aids}

1 Mirko D. Grmek, Histoire du Sida. debut et origine d'une pandémie actuelle Paris, Payot, $1989 \mathrm{c}$ David, Black. The plague years $a$ chronicle of Aids, the epidemic of our times. Nova York, Simon and Schuster, 1986
A Aids irrompeu no cenário público no início da década de 1980. A forma brutal como se manifestava, seu aspecto misterioso, incompreensível e inexplicável deixaram perplexos tanto os médicos e cientistas quanto os leigos. Inicialmente, foi identificada como uma síndrome que acometia indivíduos do sexo masculino que tinham em comum a homossexualidade. A identificação clínica ocorreu, primeiro, nos Estados Unidos, assim como a classificação dos homossexuais masculinos como grupo de risco - em que é maior a incidência da doença quando comparada com a população em geral - quase exclusivo. Posteriormente, constatou-se a ocorrência da doença em usuários de drogas injetáveis e hemofílicos. Aumentaram, então, os grupos de risco, mas a doença continuou sendo entendida como exclusiva desses grupos. ${ }^{1}$

Observações clínicas e epidemiológicas indicavam que era transmitida por via sexual e sangüínea, e que um vírus era o provável agente etiológico. Desde o início, acreditou-se nessa hipótese, que foi demonstrada em 1983, simultaneamente na França e nos Estados Unidos, por Luc Montagnier, do Instituto Pasteur, de Paris, que isolou o vírus que denominou LAV, e Robert Gallo, do National Cancer Institute, que o denominou HTLV-III. A questão da primazia da descoberta e a associação do vírus ao grupo HTLV despertaram grande controvérsia. Em maio de 1986, uma Comissão Internacional de Nomenclatura de Virologia decidiu unificar e universalizar o nome do vírus, que passou a se chamar HIV.

A disseminação da doença foi acompanhada na imprensa por matérias que, por um lado, divulgavam os esforços da comunidade científica para debelar o HIV, e, por outro, reforçavam, no imaginário coletivo, a noção de que a Aids era efeito necessário de condutas reprováveis do ponto de vista da moralidade preconizada pelo status quo.

Quando surgiram os primeiros casos no Brasil, em 1981, absorveu-se imediatamente a categorização criada nos Estados Unidos e 
na Europa. Trata-se de uma síndrome de imunodeficiência adquirida. A causa provável é um vírus, com tropismo predominante para as células do sistema imunológico. Provoca, assim, disfunçôes da resposta imune e permite a instalação de doenças oportunistas que evoluem para formas graves. Tem como grupos de risco os homossexuais masculinos, os usuários de drogas injetáveis e os hemofílicos. Não existe tratamento que restaure o sistema imunológico do indivíduo infectado, nem vacina que proteja contra a doença. Portanto, ela se torna sinônimo de morte dos homossexuais masculinos, dos toxicômanos e, logo, dos hemofílicos.

Só que eles decidem não morrer em silêncio. Numa conjuntura em que se instituía no Brasil uma constituição voltada para a cidadania, preconizando o direito de todos à saúde garantida pelo Estado, a Aids contribuiu para o avanço da luta pela qualidade do sangue dos centros hemoterápicos e catalisou a mobilização de doentes e infectados em organizações não-governamentais (Ongs) que passaram a defender o direito à informação sobre a doença e a exigir medidas concretas de controle por parte dos poderes públicos.

A comunidade científica produziu grande quantidade de trabalhos sobre a Aids, mas seus propósitos para conceber um modelo adequado da evolução do vírus não estiveram isentos de concepções morais. Em conseqüência disso, os esforços que fizeram os cientistas para uma eficaz apreensão da problemática do HIV mantiveram-se muito aquém da velocidade de disseminação da doença, mostrando-se esta maior que a do raciocínio clínico e epidemiológico. Não só o crescimento da Aids foi exponencial, como ultrapassou os limites dos grupos de risco anteriormente demarcados, acometendo homens heterossexuais e um número cada vez maior de mulheres. Segundo a Organização Mundial de Saúde (OMS), o número de casos no mundo era de 408 em 1982 e 1.573 já no final daquele ano; 5.077 em 1983 e 12.174 no final de 1984. No Brasil, em 1982 havia apenas sete doentes e, em junho de 1990, subiu para 12.405.

Logo ficou claro que os esforços para o controle da doença deviam se concentrar na ação preventiva - prevenir o contágio - até por não se conhecer procedimento terapêutico eficaz para a sua cura. A qualidade do sangue nos centros de hemoterapia, um problema bastante antigo, tornou-se questão inadiável de grande interesse público, por causa da Aids transfusional. Em 1985, o governo federal alegava que o combate à doença não era prioritário, em vista de outros problemas de saúde no Brasil. A pressão social obrigou-o a tornar compulsório o teste anti-Aids na triagem do sangue, em janeiro de 1988.

Naquele mesmo ano, no âmbito do Ministério da Saúde, foi criado um programa nacional com o objetivo de reduzir a 
morbidade e a mortalidade causadas por doenças sexualmente transmissíveis, inclusive a Aids, e de melhorar a qualidade de vida das pessoas infectadas pelo HIV. A disseminação de informações sobre a doença e o uso do preservativo como principal instrumento de proteção contra a mesma foram consideradas as bases da estratégia perseguida pelo Programa Nacional de Doenças Sexualmente Transmissíveis (PNDST e Aids), cujo slogan é "Informação: a vacina mais eficiente contra a Aids." Além de produzir material informativo constituído por cartazes, folhetos, cartilhas, livretos, manuais que veicula nos vários meios de comunicação, o Ministério da Saúde começou a financiar algumas Ongs que já trabalhavam nesse sentido.

Observando ao longo do período de existência da Aids, constataremos inflexões nas campanhas de prevenção contra a doença. No início, elas possuíam padrão uniforme, usado indistintamente em todos os países, e não tinham sensibilidade para as diferenças culturais e etárias. As campanhas governamentais eram agressivas e contribuíam para disseminar uma postura discriminatória em relação ao doente e pouco esclarecedora em relação à doença. Utilizavam frases impactantes como: "A Aids mata!", "Aids, você precisa saber evitar", ou ainda "Quem vê cara não vê Aids."

Na segunda metade da década de 1980, quando se constatou a alta incidência da infecção pelo vírus HIV entre os hemofílicos e veio à tona o problema da contaminação do sangue nos centros hemoterápicos, houve forte pressão social para que o governo assumisse o combate à Aids de forma clara e estrutural. Mobilizada de várias formas pela doença, a própria sociedade civil criou Ongs cuja linha de ação tem sido, fundamentalmente, despertar a consciência e a solidariedade em torno da questão da Aids e manter a pressão sobre os poderes públicos. A campanha de prevenção promovida pelo governo, ainda com o apelo "Aids, você precisa evitar", introduziu, então, a questão do sangue em seus cartazes: "Doar sangue é um ato de amor", "Amor não mata."

No início da década de 1990, com o Programa Nacional DST e Aids já criado, e a existência de vultosos recursos, possibilitados por uma estratégia mundial de controle da doença, houve produção maciça de material de alta qualidade gráfica destinado a educar e informar públicos específicos. Guiada pela análise da incidência da doença e dos comportamentos associados a ela, a campanha deixou de ser genérica e passou a levar em conta as diferenças étnicas, econômicas e culturais.

No início, vigorou ainda o conceito de grupo de risco, o que justificava uma grande produção voltada para os homossexuais masculinos, os profissionais do sexo e os usuários de drogas injetáveis. Não só isso, mas também o uso de mensagens agressivas, 
como esta, veiculada pelo Ministério da Saúde em rádio e televisão em 1991: "Eu tenho Aids e não tenho cura." Com a crescente mobilização das Ongs, apoiadas pelo próprio ministério, e de outras iniciativas particulares, tornaram-se mais corajosas as iniciativas educacionais destinadas a prevenir a Aids, principalmente aquelas relacionadas ao uso compartilhado de drogas injetáveis. Os cartazes que tratam da questão têm imagens fortes, dramáticas mesmo, que imediatamente colocam o público em cena: "Não transe com quem injeta drogas... se não estiver usando camisinha" ou "A linha que separa a vida da morte é tão fina quanto uma agulha."

Verificamos, depois, uma grande preocupação do Programa DST e Aids com os jovens e adolescentes, que também foram incluídos no público-alvo da campanha contra as drogas injetáveis. O trabalho direcionado para esses grupos pretendeu, fundamentalmente (e deve continuar nesta mesma linha), incorporar o uso da camisinha ao seu despertar para as atividades sexuais. Em geral, cartazes com muitas cores apresentavam jovens saudáveis que se orgulhavam de ser bem informados e que não dispensavam o uso do preservativo. As mensagens eram positivas, no sentido de o adolescente passar a "prevenir-se do vírus e não das pessoas". Tanto a campanha de 1993 como a de 1994 tiveram esse sentido: "Você precisa aprender a transar com a existência da Aids."

Mais recentemente, o público-alvo das campanhas oficiais foi o de mulheres. Buscou-se, em primeiro lugar, elevar sua autoestima para que enfrentassem a negociação ou a recusa de uma relação sexual, sempre que necessário. A campanha destinada às mulheres pretendia que elas rompessem com os preconceitos e passassem a encarar o preservativo como algo de sua responsabilidade também. Assim como os homens, deviam estar preparadas para que a ausência da camisinha do lado do parceiro não fosse motivo para deixar de usá-la. O slogan da campanha era: "Quem se ama se cuida."

As primeiras estatísticas da incidência da Aids no Brasil estabeleciam que havia apenas uma mulher com HIV para cada cem homens infectados. Hoje mostram que para cada três homens corresponde uma mulher contaminada, e muitas delas são casadas. Há, inclusive, um cartaz que expressa bem essa realidade ao dizer que a aliança de casamento não é garantia contra a infecção, só a camisinha - mostrando-a semelhante ao anel, antes de ser desenrolada.

Há uma grande preocupação com as mulheres, vítimas da pobreza, da falta de informação, de preconceitos, tabus e mitos de toda ordem que dificultam sua capacidade de negociar com os parceiros o uso da camisinha, como mostra um trecho da 
história em quadrinhos Toda vez e sempre. Em geral, os parceiros mantêm outros relacionamentos sexuais, sem proteção, ou fazem uso de drogas injetáveis, sem revelar essas práticas às mulheres com que se relacionam. Com isso, elas estão se tornando o segmento mais vulnerável à epidemia. A campanha quer ensinálas a dizer 'não' todas as vezes que a relação sexual ameaçar acontecer sem preservativo.

Além de procurar atingir populações específicas, o governo federal promove campanhas pontuais, em eventos determinados, como, por exemplo, o carnaval. A cada ano lança mão de slogans diferentes que propõem basicamente uma coisa: o uso da camisinha na relação sexual com o eventual parceiro(a).

Independentemente do acúmulo de conhecimento acerca da doença, as campanhas oficiais sofrem visíveis avanços e retrocessos em sua capacidade de transmitir informações claras e isentas de preconceitos. A campanha mais recente, cujo slogan é "Assim pega, assim não pega", é, por exemplo, menos esclarecedora que a polêmica campanha do "Bráulio", veiculada pela televisão em 1996. "Viva com prazer, viva o sexo seguro" - tema de outra campanha - afirma positivamente o uso da camisinha. A expressão sexo seguro não é do jargão técnico, e sim um conceito que se quer incorporar ao cotidiano das pessoas, junto com o uso do preservativo na prática sexual.

Não resta dúvida de que as Ongs têm contribuído muito na tarefa de informar a população e de mobilizá-la contra a Aids. A cidadania e a solidariedade aos soropositivos e aos doentes estão na pauta de discussões desses grupos, e informam suas ações. "Viver a vida positivamente" expressa o apoio àqueles indivíduos que se tornaram soropositivos para o HIV, mas ainda não desenvolveram a doença. A tônica do material gráfico produzido por essas organizações é o respeito à vida.

O conceito grupo de risco é inaceitável nos dias atuais. Ele resulta em forte discriminação àqueles que são enquadrados em um ou outro grupo, e em perigosa negligência com a prevenção dos que estão fora, considerando-se imunes. O comportamento epidemiológico da doença contradisse esse conceito. Hoje é fundamental trabalhar com a idéia de comportamento de risco que, se adotado, torna qualquer pessoa vulnerável. A Aids precisa ser encarada, cada vez mais, como problema de todos, como expressou Herbert Daniel (jornalista brasileiro, fundou, em 1989, o Grupo Pela Vidda, uma Ong voltada para a questão da Aids. Morreu, vítima da Aids, em 29 de março de 1992) no discurso que proferiu na Corte Internacional de Haia, em maio de 1991: "Não acontece comigo. Acontece conosco. Acontece com a humanidade, hoje."

Algumas imagens de cartazes internacionais que selecionamos para esta seção indicam que existe, concretamente, uma estratégia 
mundial de combate à doença, materializada, por exemplo, no $1^{2}$ de dezembro - Dia Mundial de Luta contra a Aids —, instituído pela Assembléia Geral das Nações Unidas em 1988. A cada ano a data é celebrada com informações atualizadas sobre a prevenção e assistência à Aids. O Dia Mundial pretende não só divulgar mensagens de solidariedade a todos os recantos do mundo, como estimular a discussão e a ação entre pessoas que habitualmente não se sentem ameaçadas pela Aids, de modo a forjar mais e maiores comprometimentos contra a difusão da pandemia.

\section{Dilene Raimundo do Nascimento}

pesquisadora da Casa de Oswaldo Cruz Av. Brasıl, 4036 sala 401

21040-360 - Rio de Janeiro - RJ Brasil

$\mathbf{1}$

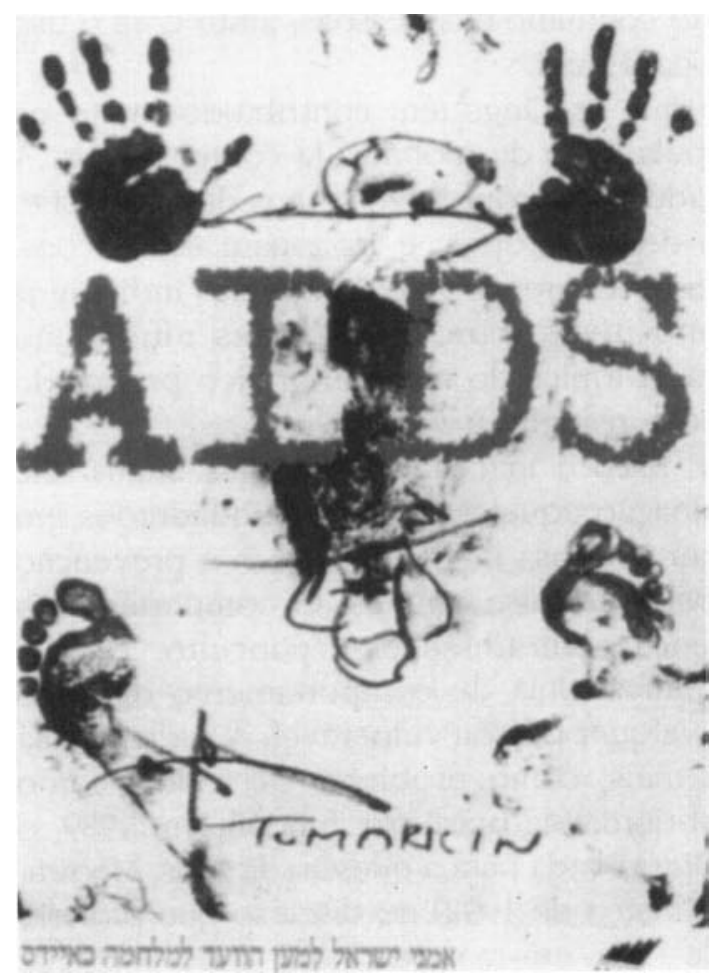

2

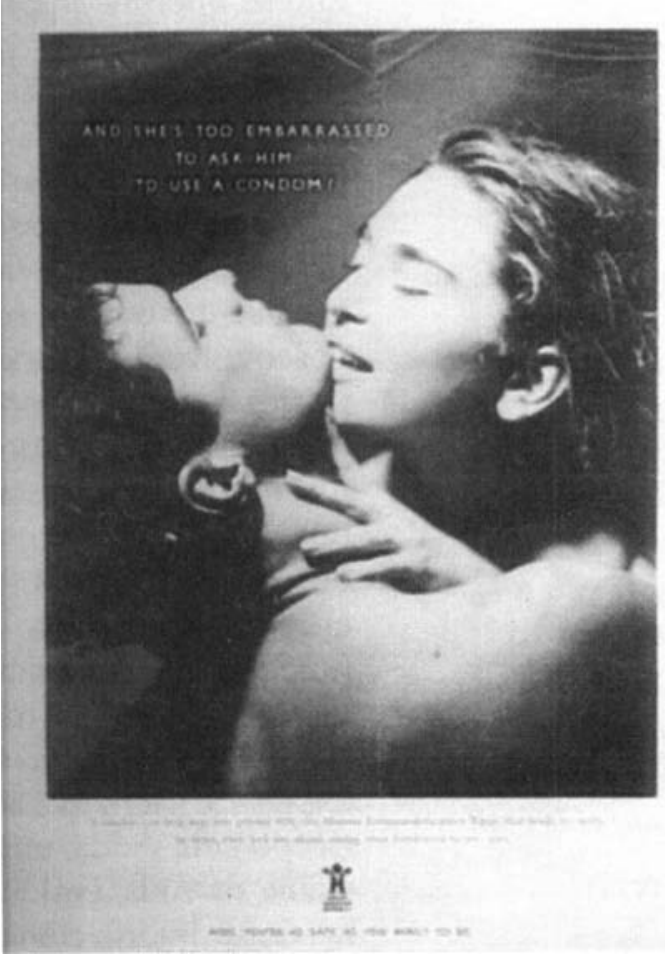

Belas imagens e legendas fortes, alertando para os prazeres do sexo seguro, são a tônica de cartazes de vários países, como Israel (1) Estados Unidos (2 e 6), França (3), Nigéria (4), Alemanha (5). (Reproduções obtidas na revista Capricho, ano 40, no 3, São Paulo, Editora Abril, mar. 1993.) 
3
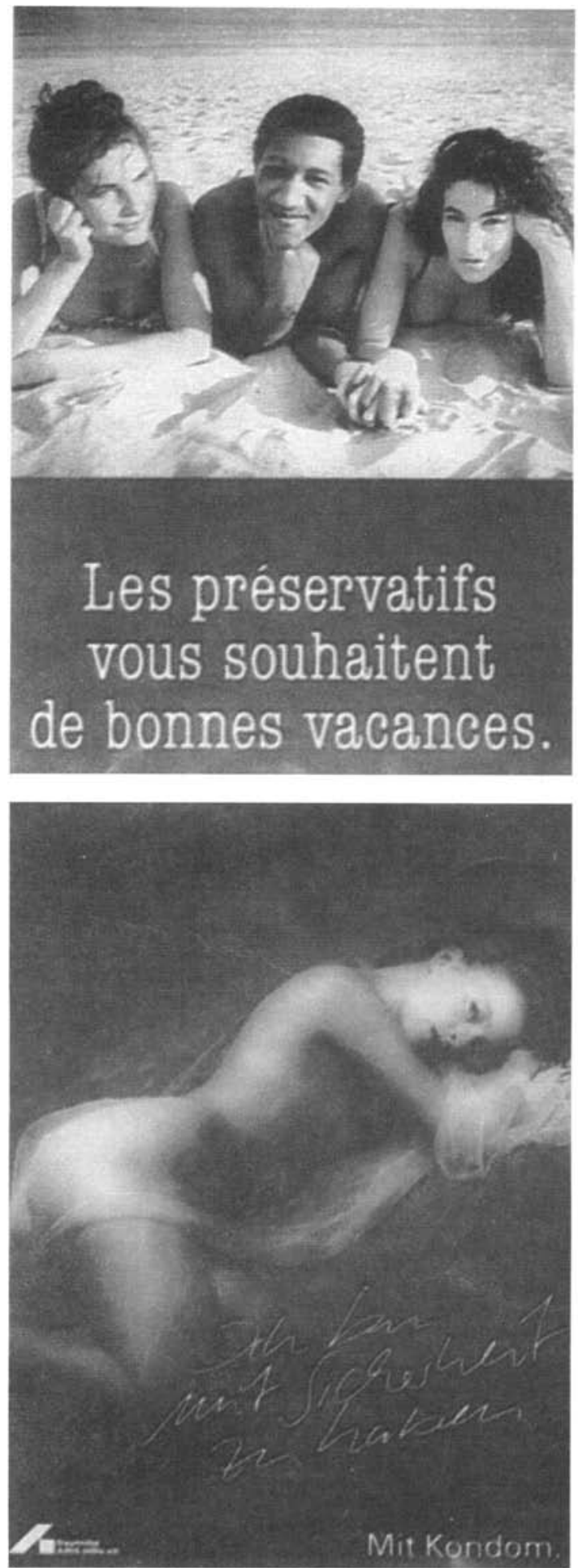

4
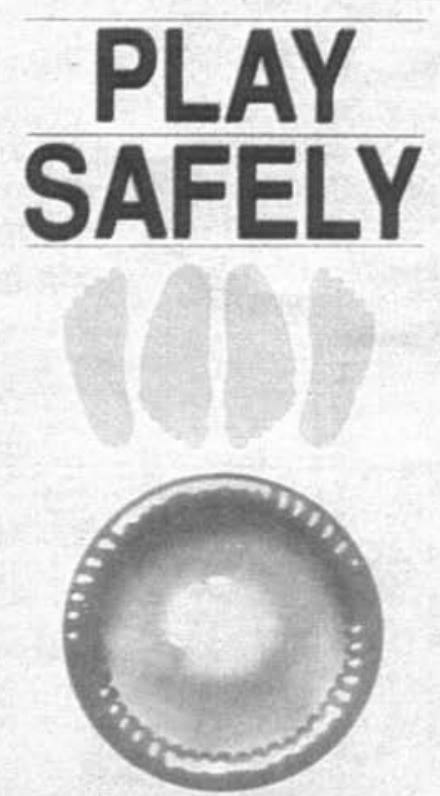

Usea Condom

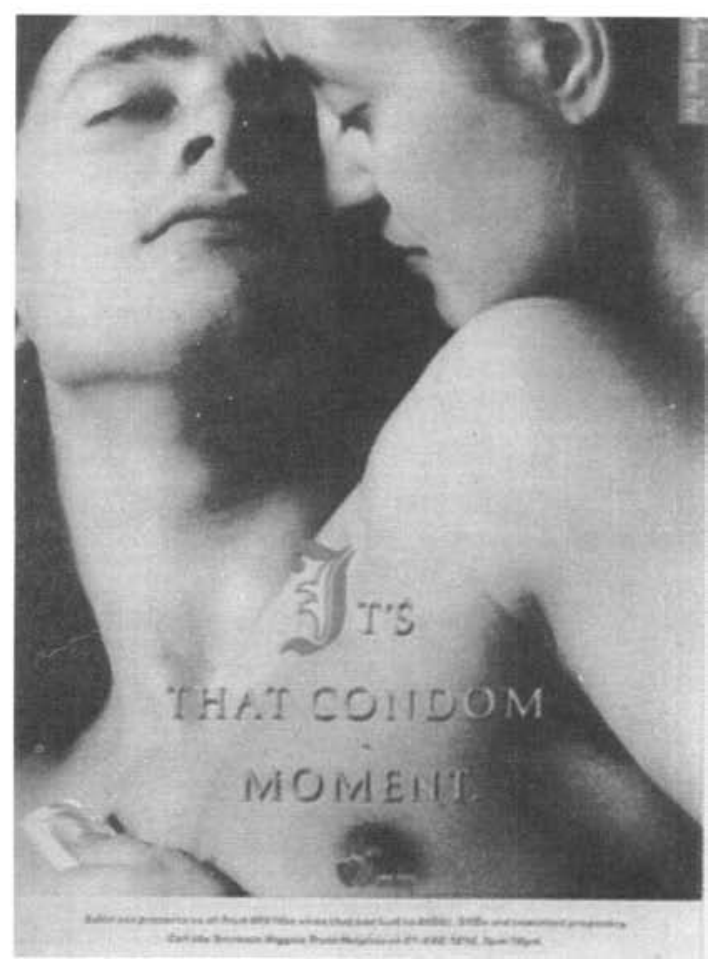

6 

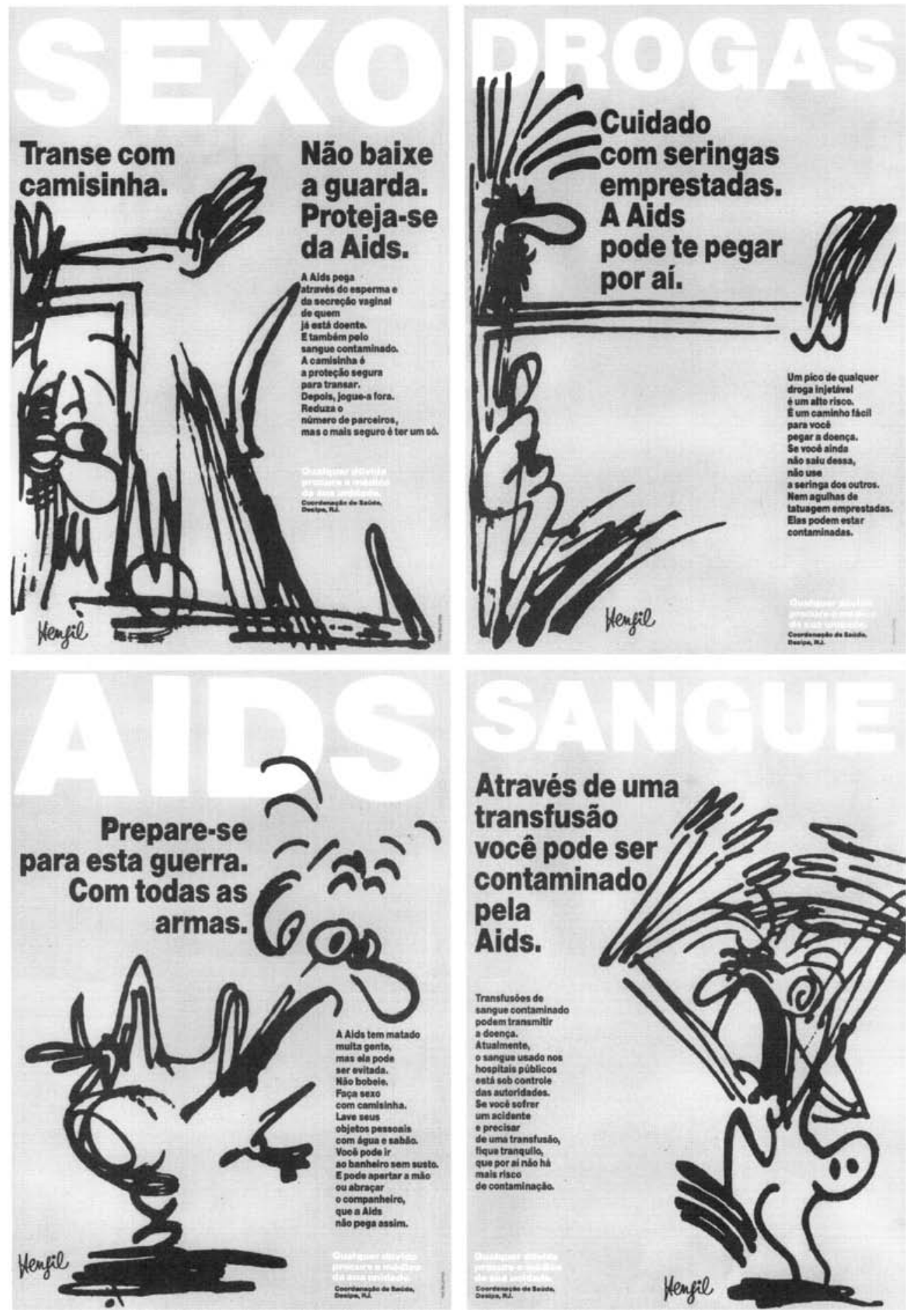

Essa série foi veiculada em campanha dirigida aos presidiários do Rio de Janeiro, para que se submetessem ao teste Elisa, que detecta o vírus. Censo realizado pelo Núcleo de Saúde do Departamento do Sistema Penitenciário constatou que $18 \%$ dos presos do estado (em torno de dez mi) eram soropositivos. Acervo: arquivo particular. 


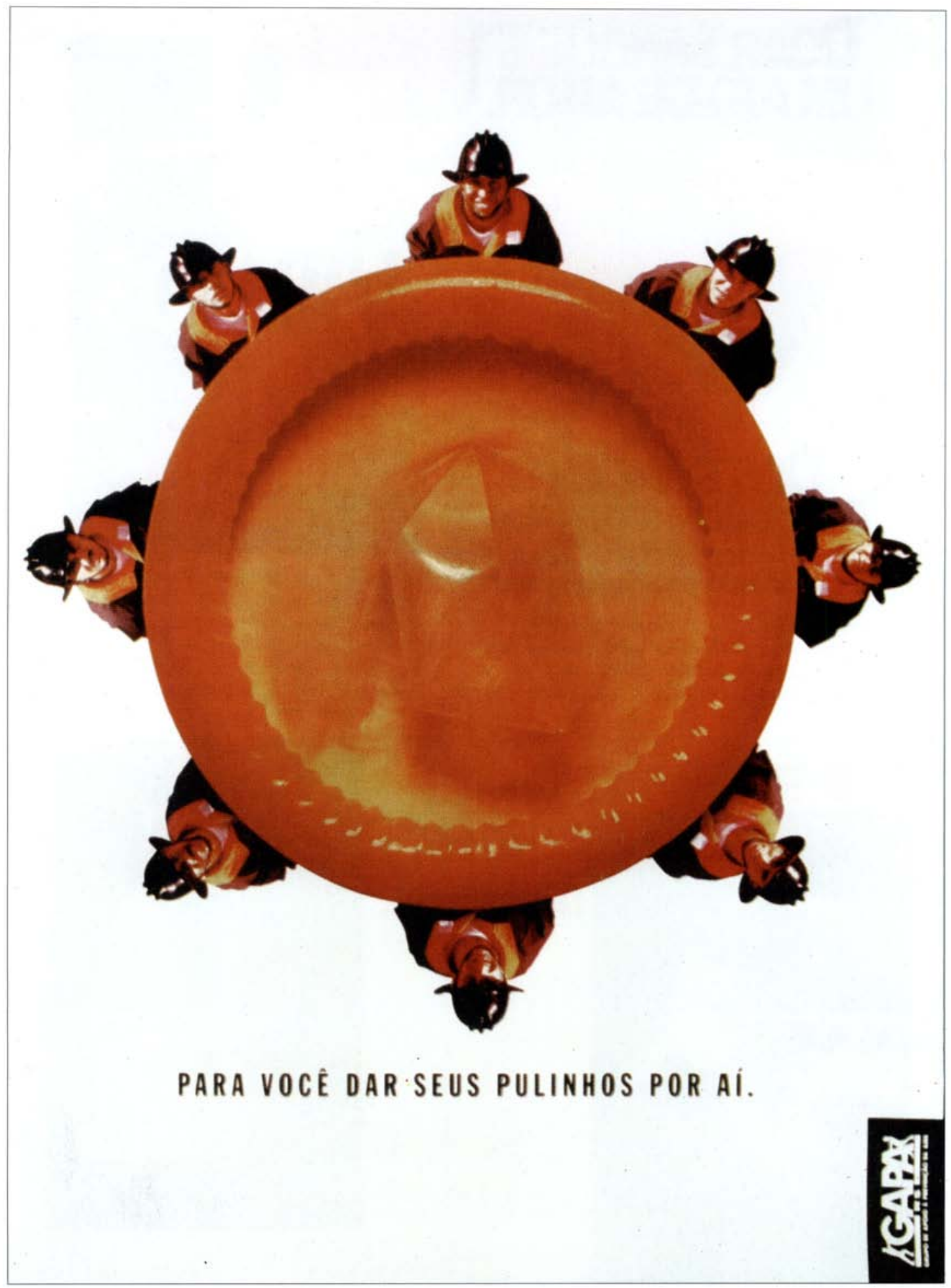

Bom gosto e refinamento neste alerta para o uso de preservativos. Grupo de Apoio e Prevenção da Aids (Gapa-RJ). Acervo: COC. 


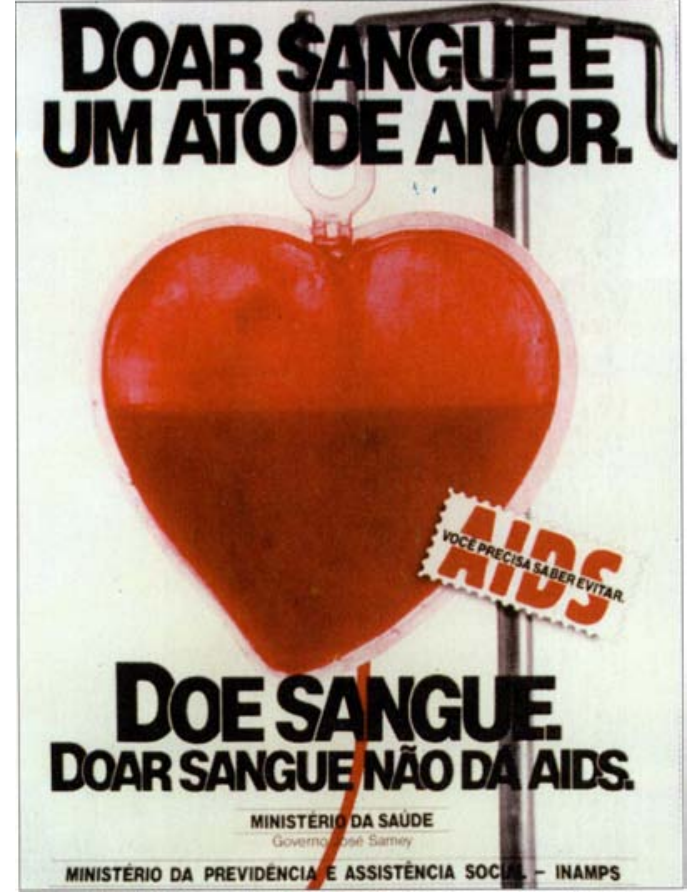

O impacto da Aids transfusional é a tônica da campanha dos ministérios da Saúde e da Previdência e Assistência Social. Acervo: Unidade de

Documentação e Comunicação (UDC/PNDST e Aids).

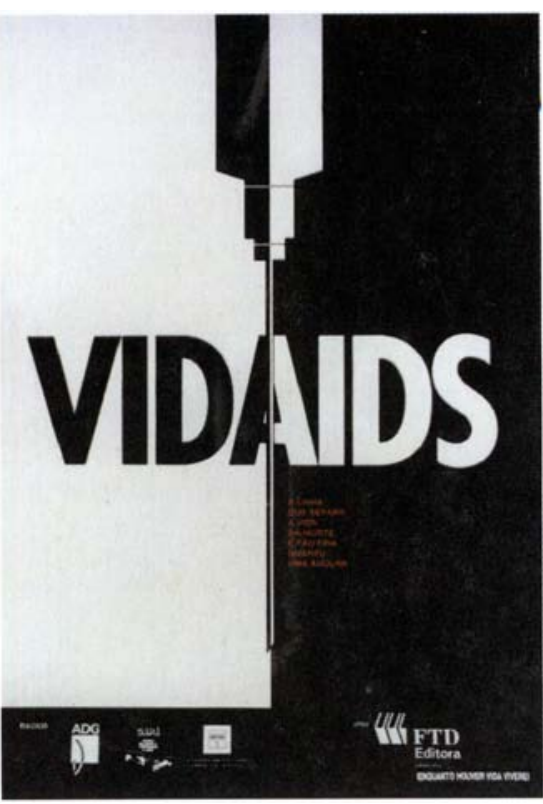

Cartaz feito para o concurso 'Aids e adolescência', promoção da Associação de Designers Gráficos, Grupo de Apoio e Prevenção da Aids (Gapa), Serviço Nacional do Comércio (Senac), FTD Editora, em 1992. Acervo: COC.

\section{NÃO TRANSE COM QUEM}
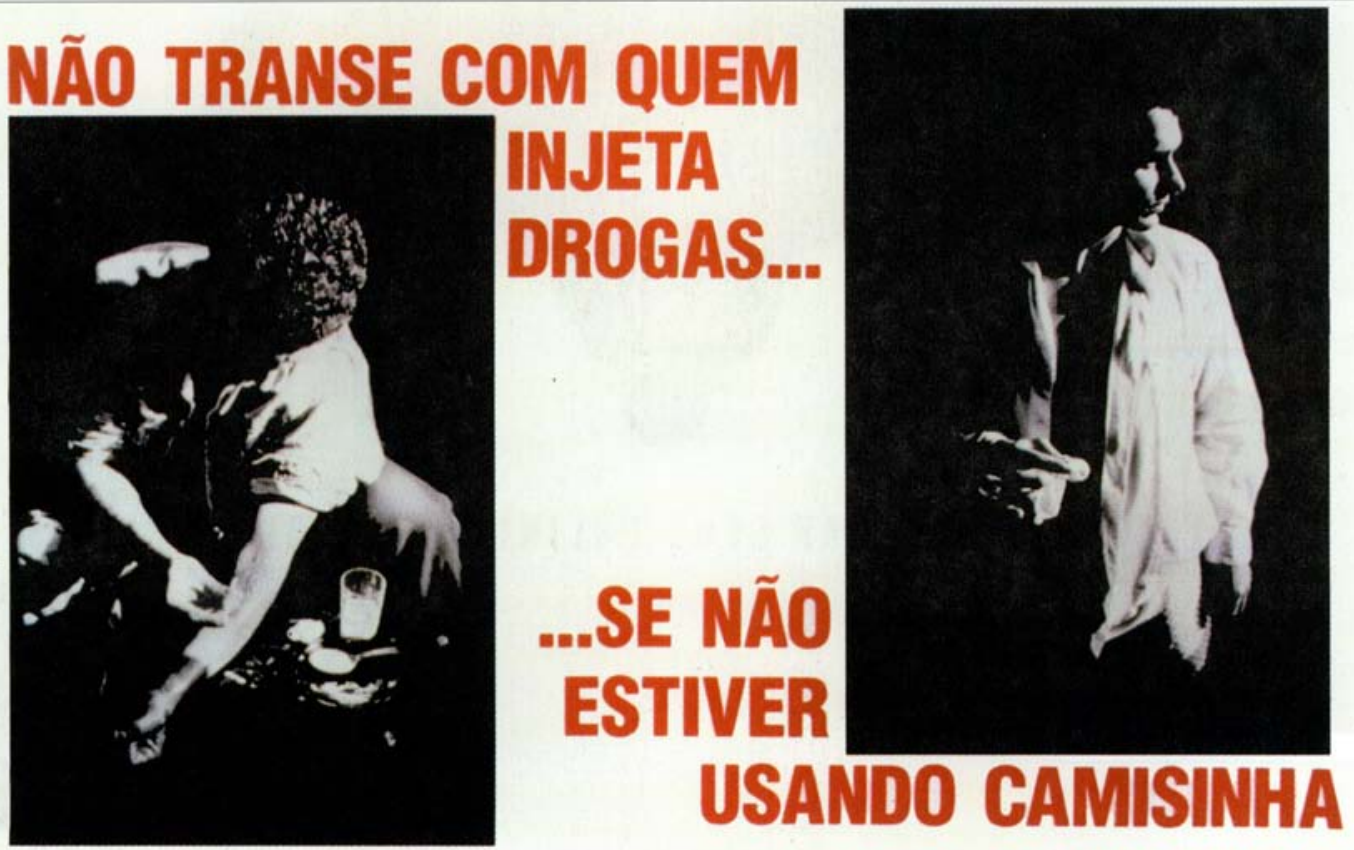

Outro alerta aos usuários de drogas injetáveis. Acervo: UDC/PNDST e Aids. 


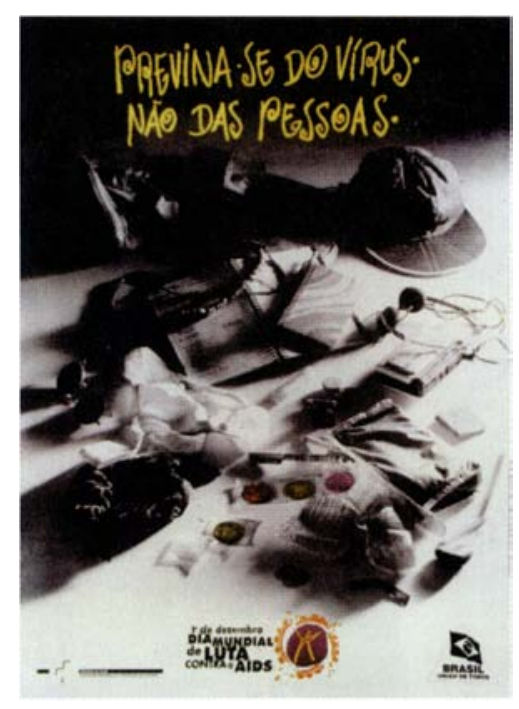

O adolescente é o alvo do cartaz em comemoração ao Dia Mundial de Luta contra a Aids, 1993 (MS/UDC/PNDST e Aids). Acervo: UDC.
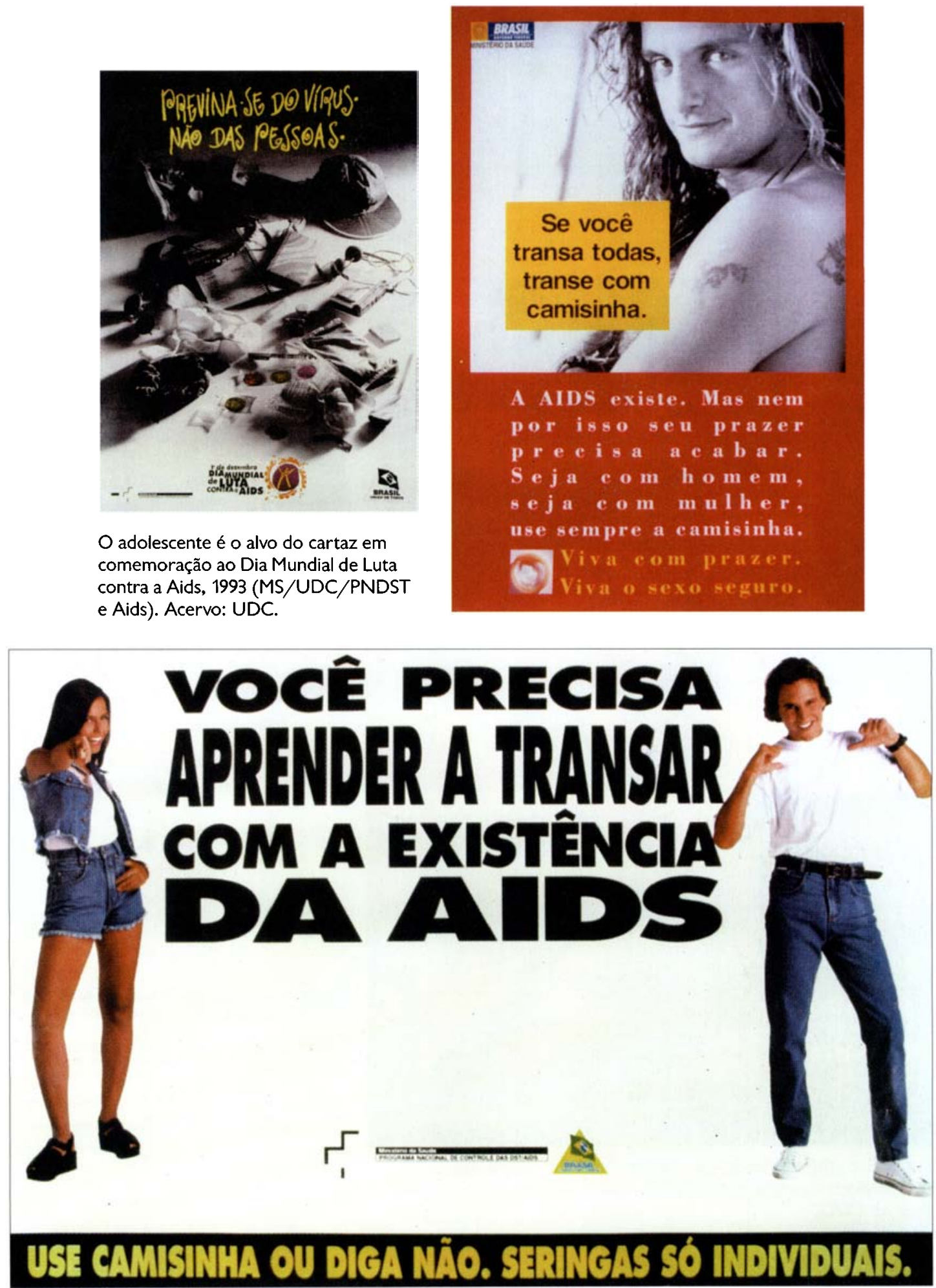

Campanhas de prevenção do Ministério da Saúde, 1994 e 1996 (MS/UDC/PNDST e Aids). Acervo: UDC. 

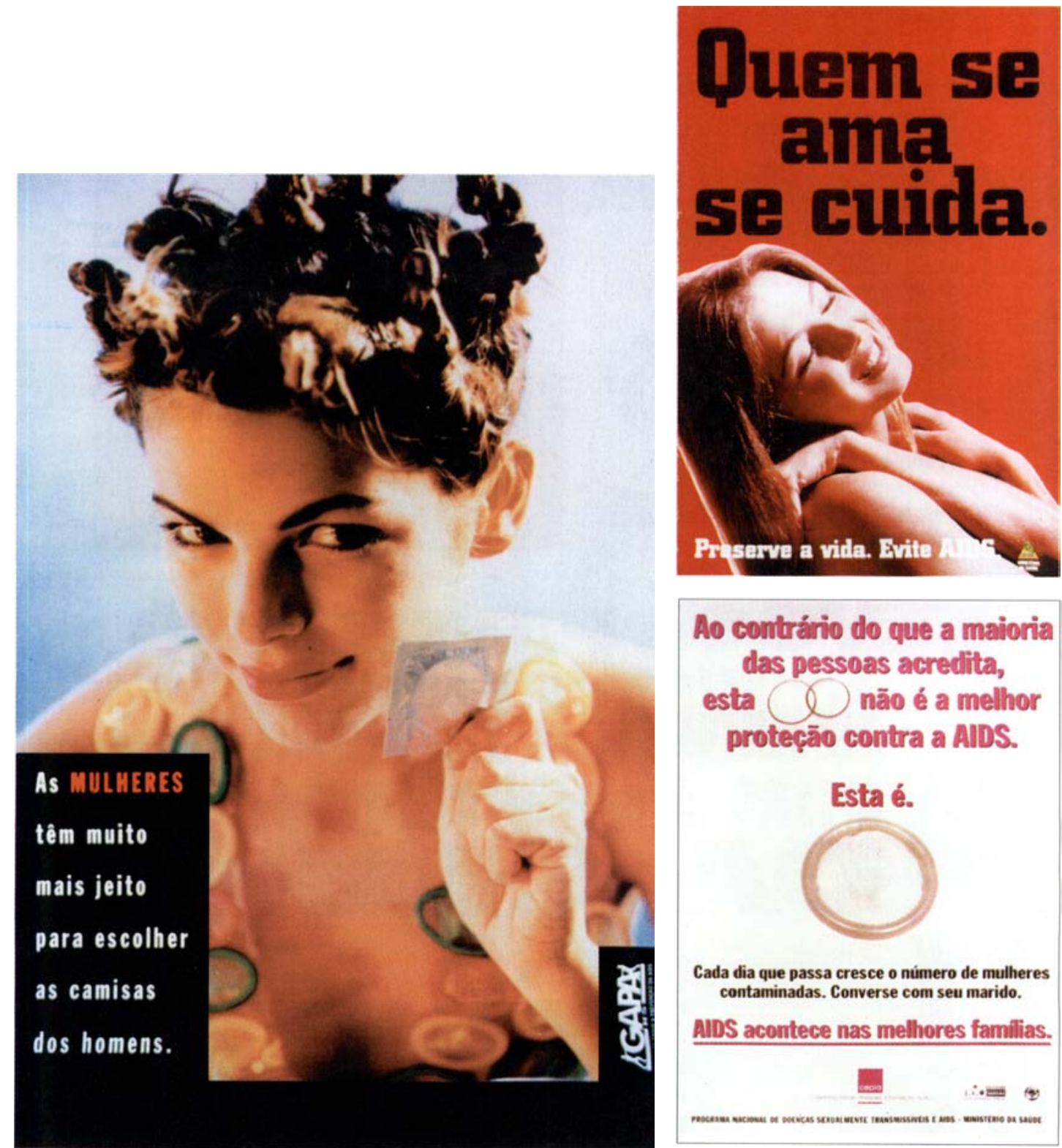

Ao contrário do que a maioria das pessoas acredita, esta@ näo é a melhor proteção contra a ADS.

Esta é.

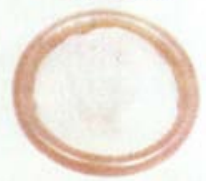

Cada dia que passa cresce o nuimero de mulheres contaminadas. Converse com seu marido.

ADS acontece nas melhores familias.

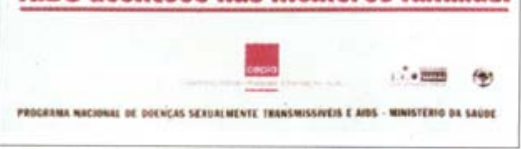

Em 1995, o público-alvo das campanhas oficiais foi, em especial, o de mulheres, cujo índice de contaminação cresce assustadoramente. Acervo: COC. 


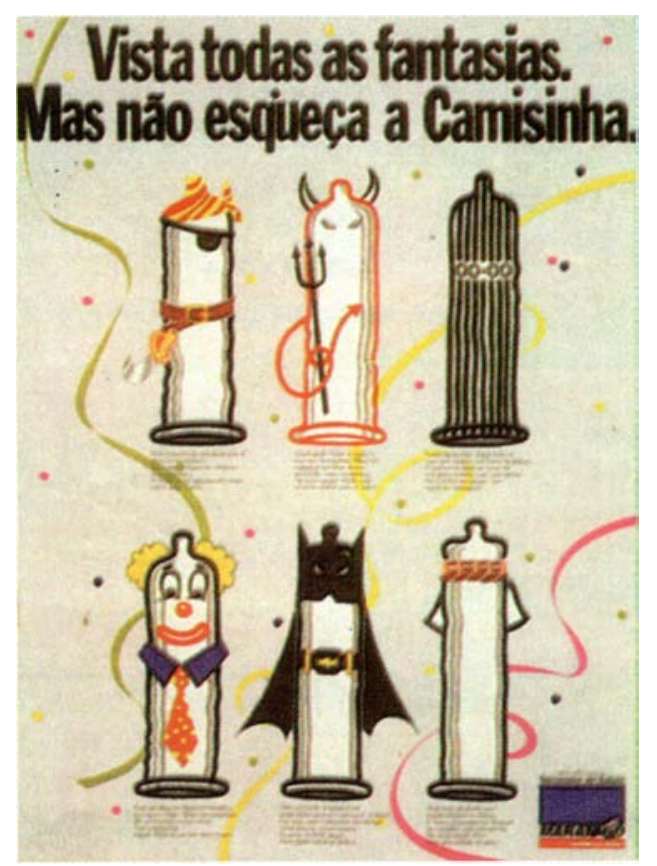

A cada ano, o governo federal lança mão de um slogan diferente no carnaval. Acervo: UDC/MS.
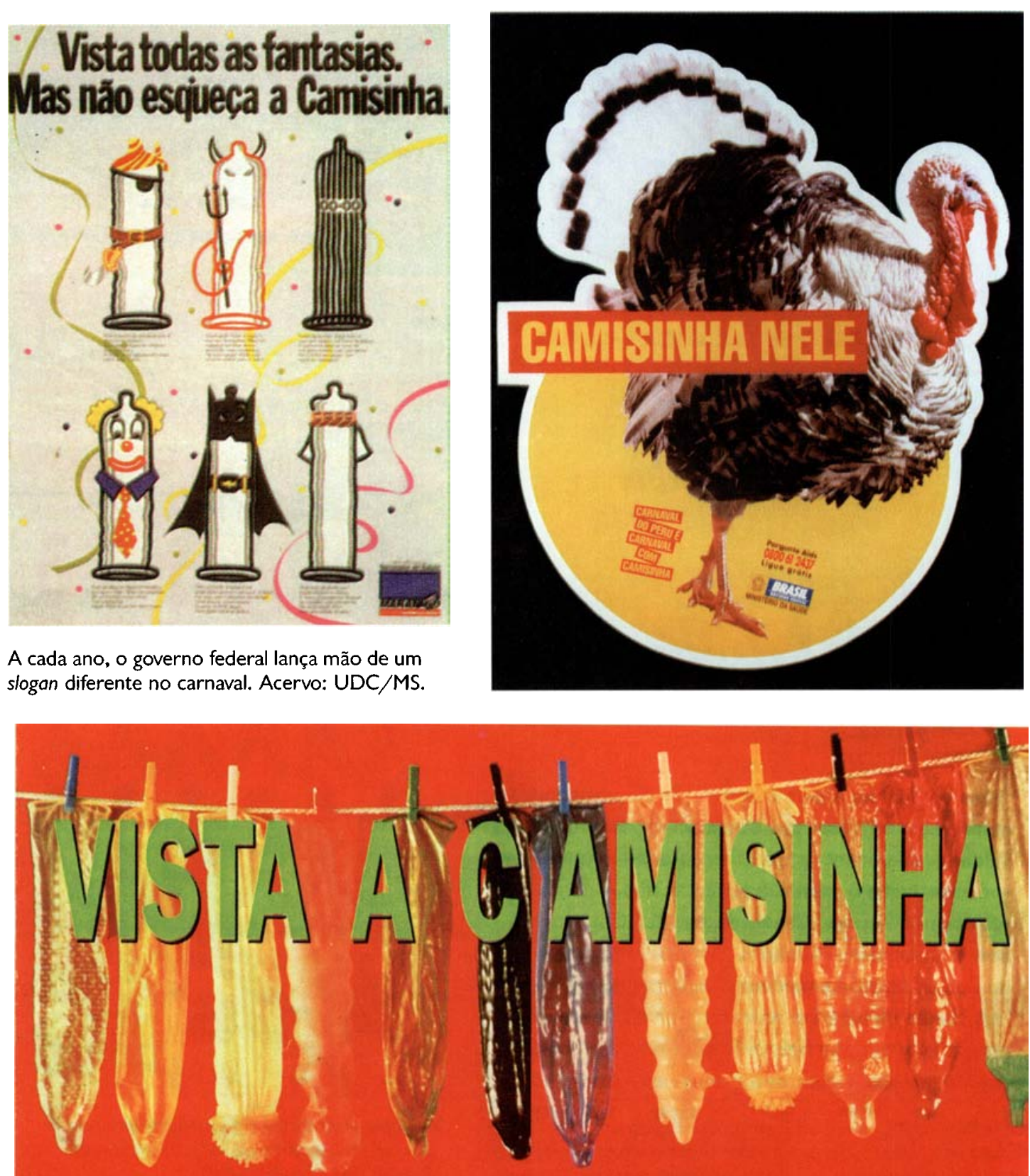

Sinn, isto \& una ca mpanha declarada.

Mais ainda: uma ordem. A Aids é uma doença mortal e, infelizmente, ainda não tem cura. Ninguém sabe quando vai ter. Ninguém sabe também, olhando para uma pessoa, se ela tem o virus. E o virus é transmitido, entre outras coisas, pelo esperma e pelos fluidos vaginais. Por isso é fundamental, imprescindivel e obrigatório o uso da camisinha quando transar.

Reprodução de abertura de matéria da revista Capricho (ano 40, n 3, pp. 36-7, São Paulo, Editora Abril, mar. 1993, foto: Agência All Action Stills). 


\section{VIVER A VIDA POSITIVAMENTE}

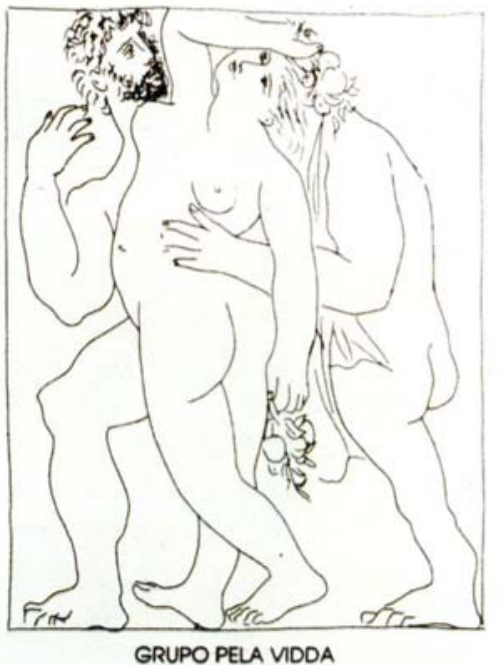

Desenhos de Pablo Picasso ilustram cartilha do

Grupo Pela Vidda, com explicações sobre o vírus, o teste e as formas de transmissão. (Cuidando de alguien com Sida, Centros para Control de la Enfermedad, Atlanta, Estados Unidos, 1992). Acervo: COC.

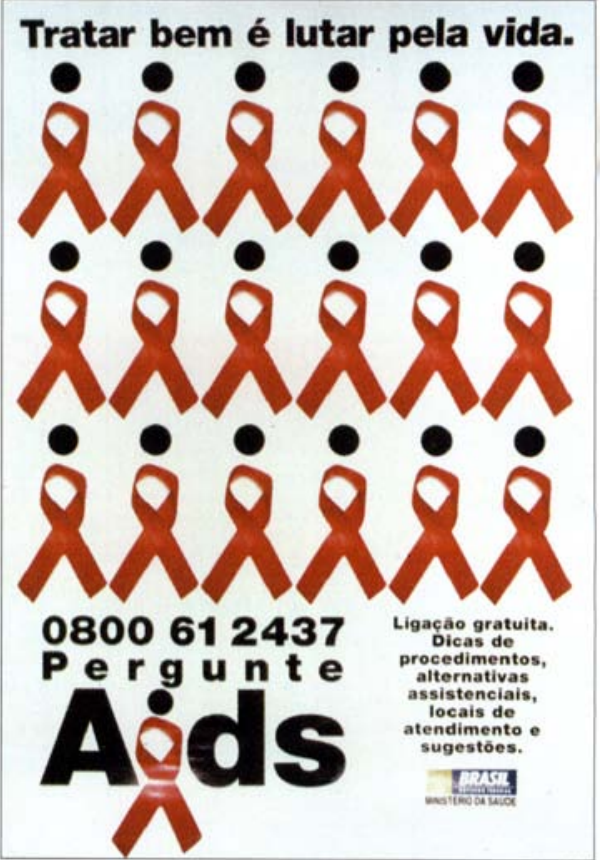

Símbolo internacional da solidariedade aos portadores do vírus da Aids. Ministério da Saúde, 1966. Acervo: UDC. 


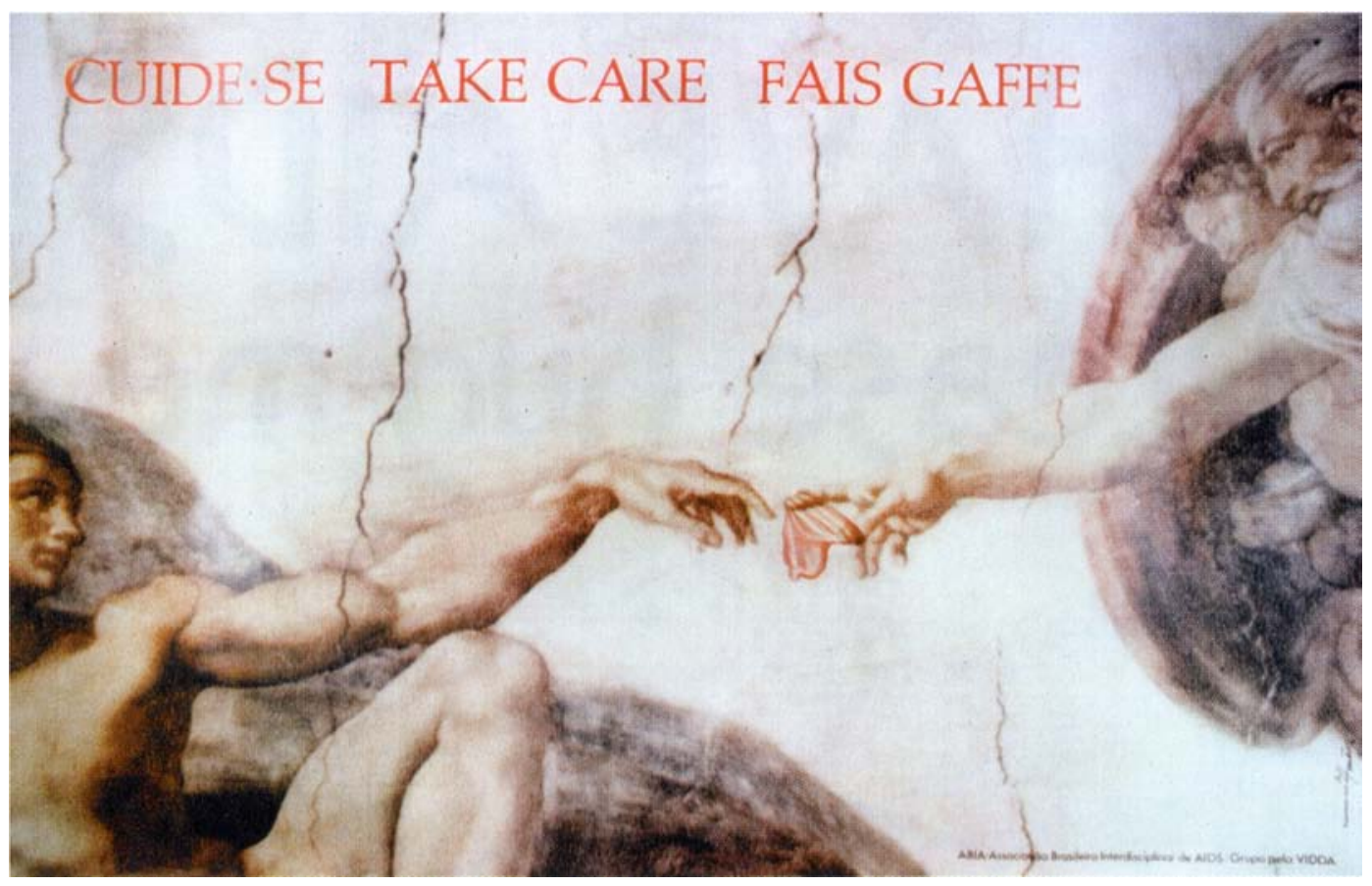

Detalhe de Criação do mundo, de Michelangelo Buonarroti. Cartaz de 1991 produzido em parceria pela Associação Brasileira Interdisciplinar de Aids e Grupo Pela Vidda. Acervo: COC.

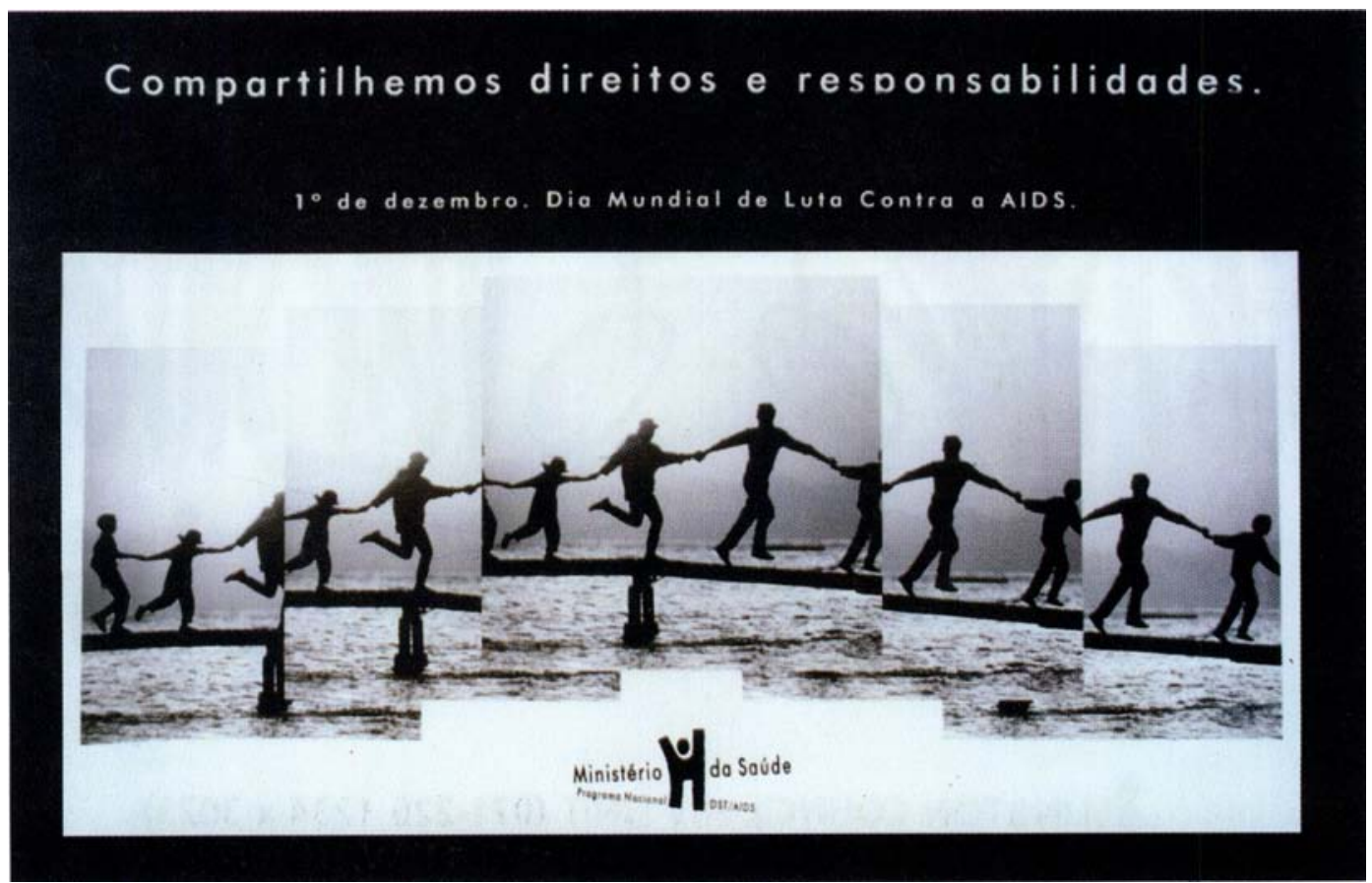

Ministério da Saúde lançou este cartaz em comemoração ao Dia Mundial de Luta contra a Aids, em 1.12.1996. Acervo: UDC. 


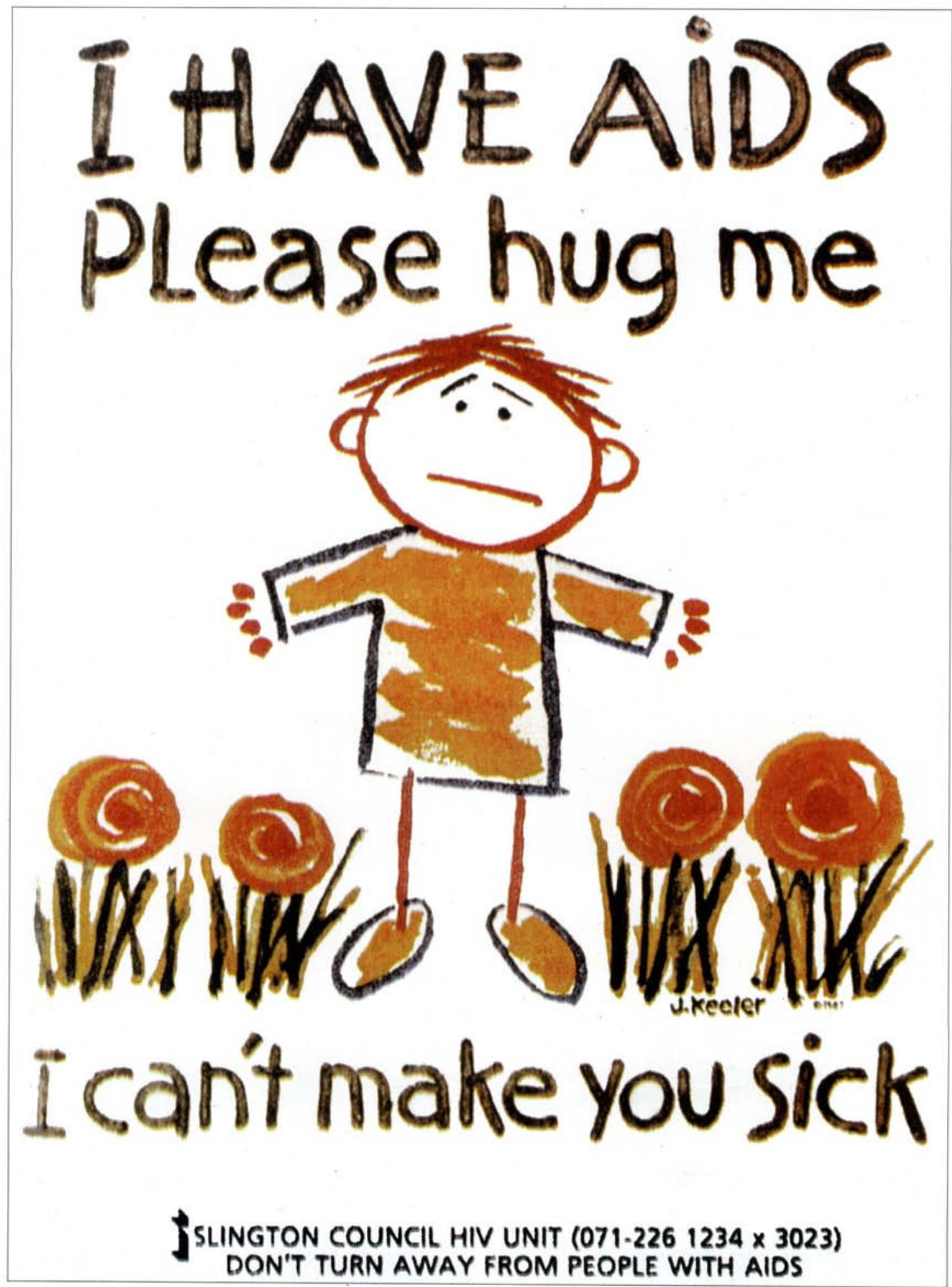

Cartaz ilustrado por J. Keeler (Slington Council HIV Unit). Acervo: COC.

Reproduções fotográficas. Roberto Jesus Oscar e Vinicius Pequeno de Souza. 